Rizqy Aji Nugroho

2301912776

LB21

\title{
Effect of Market Orientation, Marketing Capability, Product Innovation on Performance
}

Pada tahun 1997 Indonesia mengalami krisis ekonomi. Indonesia mengalami krisis ekonomi, kondisi ini berdampak pada bisnis skala besar dimana banyak bisnis yang gulung tikar bahkan bangkrut. Sedangkan dengan usaha kecil menengah yang mampu bertahan karena tidak banyak menggunakan bahan baku impor dan malah menjadi sabuk penyelamat dari dampak krisis ekonomi (Andalan \& Hikmah, 2013). Peranan usaha kecil dan menengah sangat penting dalam pembangunan ekonomi, terutama dalam penyediaan tenaga kerja dan sumber pendapatan bagi kelompok berpenghasilan rendah. Menurut Lembaga Pengembangan Perbankan Indonesia (LPPI) dan Bank Indonesia (BI) tahun 2015, faktor yang dapat mempengaruhi kinerja usaha mikro dan kecil (UMK) adalah kemampuan membaca kebutuhan pasar yang masih belum tajam, sehingga belum mampu menangkap kebutuhan yang diinginkan pasar secara akurat.

Kinerja bisnis juga dapat dinilai dari keberhasilan dalam mengelola penjualan dengan mengidentifikasi kebutuhan dan keinginan konsumen melalui penciptaan nilai pelanggan dan kepuasan pelanggan. Dalam mewujudkan tujuan tersebut, perusahaan harus mampu mengembangkan strategi orientasi pasar agar UMK dapat meningkatkan kinerja usahanya dengan baik.

\section{Business Performance}

Performance merupakan hasil evaluasi dari pekerjaan yang telah dilakukan dibandingkan dengan kriteria yang telah ditetapkan bersama (Robbins dalam Rai, 2008). Di sisi lain, bahwa kinerja adalah suatu proses atau cara kerja yang dilakukan oleh individu atau kelompok dalam organisasi (Rai, 2008). Performance merupakan hal yang penting yang harus dicapai oleh setiap perusahaan karena kinerja merupakan cerminan dari kemampuan perusahaan dalam mengelola dan mengalokasikan sumber dayanya. Kinerja adalah keluaran yang dihasilkan oleh fungsi-fungsi suatu pekerjaan dalam waktu tertentu. Pengukuran kinerja bisnis tidak cukup hanya mengukur secara finansial sebagai keuntungan, tetapi juga pengukuran non-finansial seperti kualitas layanan, kepuasan pelanggan, efektivitas program secara keseluruhan diperlukan (Kotane, 2012).

\section{Market Orientation}

Orientasi pasar adalah fokus perencanaan strategis unit bisnis dalam memenuhi beberapa tuntutan berupa semua fungsi dalam bisnis dan mampu menyerap semua informasi penting yang mempengaruhi keputusan pembelian, interfungsional dan divisi. Orientasi pasar adalah fokus perencanaan strategis unit bisnis dalam memenuhi beberapa tuntutan berupa semua fungsi dalam bisnis dan mampu menyerap semua informasi penting yang mempengaruhi keputusan pembelian, interfungsional dan divisi. 


\section{Marketing Capability}

Pengertian kapabilitas pemasaran menurut adalah suatu sistem total dari kegiatan bisnis yang dirancang untuk merencanakan, menentukan orientasi pasar, mempromosikan dan mendistribusikan barang yang dapat memuaskan keinginan dan mencapai target pasar dan tujuan perusahaan. Kemampuan pemasaran merupakan hasil kinerja kerja yang berkaitan dengan arus barang dan jasa dari produsen ke konsumen. Kapabilitas pemasaran sebagai fungsi organisasi dan serangkaian proses untuk menciptakan, mengomunikasikan, dan memberikan nilai kepada pelanggan dan mengelola hubungan pelanggan. Tujuan kapabilitas pemasaran menurut Hasan (2013) antara lain memaksimalkan keuntungan, memaksimalkan pangsa pasar, memaksimalkan penjualan, meningkatkan citra merek, meningkatkan kepuasan pelanggan, memberikan nilai dan menjaga stabilitas orientasi pasar.

\section{Product Innovation}

Inovasi produk adalah kunci keberhasilan organisasi, peningkatan pangsa pasar dan kinerja bisnis. Hal ini juga didukung oleh teori Kotabe dalam Tamamudin (2012) yang menunjukkan bahwa semakin tinggi inovasi produk yang dilakukan perusahaan akan meningkatkan kinerja perusahaan melalui keputusan pembelian yang semakin meningkat. Inovasi produk memberikan peluang bagi perusahaan untuk menarik lebih banyak konsumen. Kegiatan inovasi produk membutuhkan sumber daya perusahaan untuk mengembangkan dan mengimplementasikan ideide baru, dan kebebasan bagi individu untuk mengembangkan ide-ide mereka. Namun, sebagian pelaku bisnis belum menyadari pentingnya inovasi produk. Dengan demikian, kreativitas pemilik usaha sangat dibutuhkan untuk mendukung inovasi. 


\section{Referensi}

Lasmy, Dewi, Syahchari, D. H., Saroso, H., \& Hartono, H. (2019). Effect of market orientation, marketing capability, product innovation on performance. International Journal of Innovation, Creativity and Change, 10(8), 322-337. Retrieved from www.scopus.com 